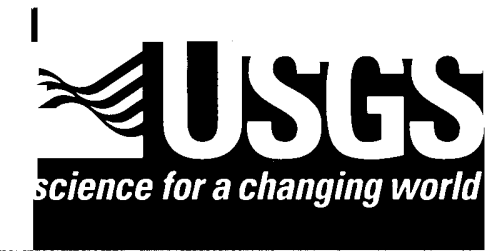

In cooperation with

Capital Area Ground Water Conservation Commission

Hydrogeologic Maps and Sections of the "400-Foot," "600Foot," and "800-Foot" Sands of the Baton Rouge Area and Adjacent Aquifers in East and West Baton Rouge, East and West Feliciana, and Pointe Coupee Parishes, Louisiana
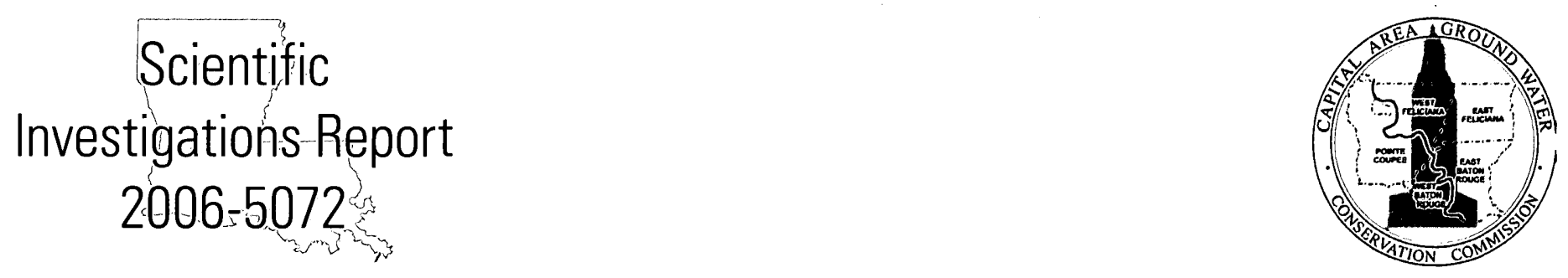

U.S. Department of the Interior

U.S. Geological Survey 



\section{Hydrogeologic Maps and Sections of the "400-Foot," "600-Foot," and "800-Foot" Sands of the Baton Rouge Area and Adjacent Aquifers in East and West Baton Rouge, East and West Feliciana, and Pointe Coupee Parishes, Louisiana}

By Jason M. Griffith

Prepared in cooperation with the Capital Area Ground Water Conservation Commission

Scientific Investigations Report 2006-5072 


\section{U.S. Department of the Interior \\ Gale A. Norton, Secretary}

\section{U.S. Geological Survey \\ P. Patrick Leahy, Acting Director}

U.S. Geological Survey, Reston, Virginia: 2006

For sale by U.S. Geological Survey, Information Services

Box 25286, Denver Federal Center

Denver, CO 80225

For more information about the USGS and its products:

Telephone: 1-888-ASK-USGS

World Wide Web: http://www.usgs.gov/

Any use of trade, product, or firm names in this publication is for descriptive purposes only and does not imply endorsement by the U.S. Government.

Although this report is in the public domain, permission must be secured from the individual copyright owners to reproduce any copyrighted materials contained within this report. 


\section{Contents}

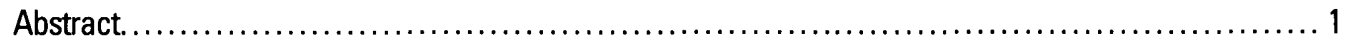

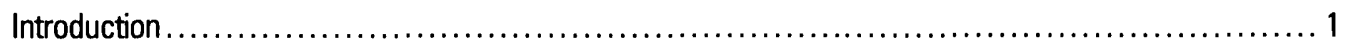

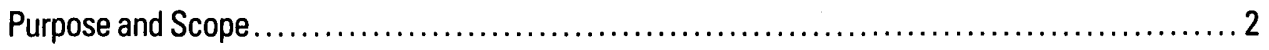

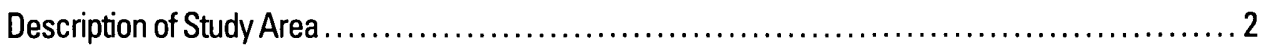

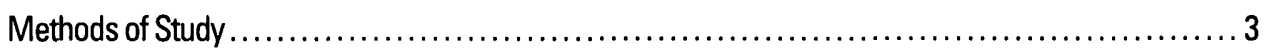

Acknowledgments....................................................... 4

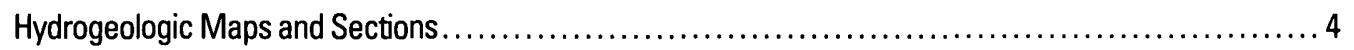

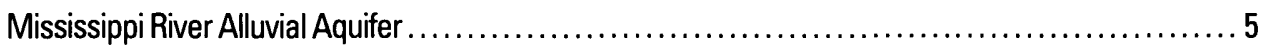

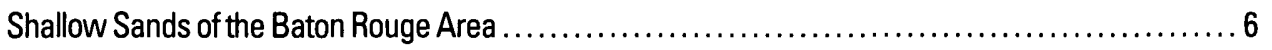

Upland Terrace Aquifer . . . . . . . . . . . . .

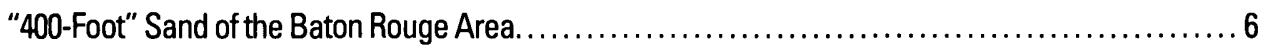

"600-Foot" Sand of the Baton Rouge Area.......................................... 6

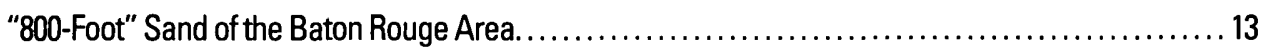

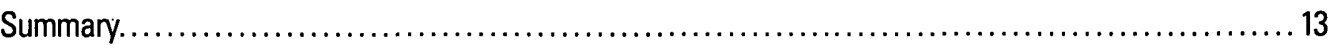

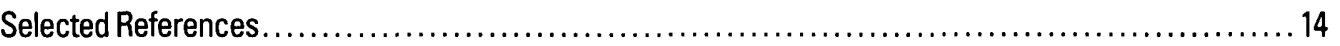

\section{Plates (in pocket)}

1. Map showing location of study area, wells with logs used for contouring structural surfaces, and trace of hydrogeologic sections in East and West Baton Rouge, East and West Feliciana, and Pointe Coupee Parishes, southeastern Louisiana

2-13. Maps showing altitude of the top or the base of the aquifer in East and West Baton Rouge, East and West Feliciana, and Pointe Coupee Parishes, southeastern Louisiana:

2. Top of the Mississippi River alluvial aquifer

3. Base of the Mississippi River alluvial aquifer

4. Top of the shallow sands of the Baton Rouge area

5. Base of the shallow sands of the Baton Rouge area

6. Top of the upland terrace aquifer

7. Base of the upland terrace aquifer

8. Top of the "400-foot" sand of the Baton Rouge area

9. Base of the " 400 -foot" sand of the Baton Rouge area

10. Top of the "600-foot" sand of the Baton Rouge area

11. Base of the "600-foot" sand of the Baton Rouge area

12. Top of the "800-foot" sand of the Baton Rouge area

13. Base of the "800-foot" sand of the Baton Rouge area

\section{Figures}

1. Diagram showing hydrogeologic units in East and West Baton Rouge, East and West Feliciana, and Pointe Coupee Parishes, southeastern Louisiana 
2-4. Diagrams showing west-to-east hydrogeologic section in East and West Baton Rouge, East and West Feliciana, and Pointe Coupee Parishes, southeastern Louisiana:

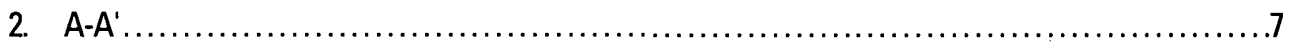

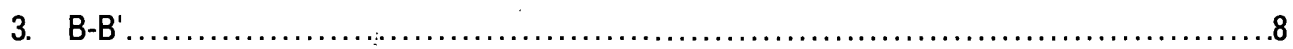

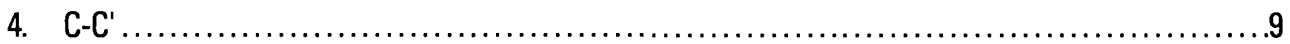

5-7. Diagrams showing north-to-south hydrogeologic section in East and West Baton Rouge, East and West Feliciana, and Pointe Coupee Parishes, southeastern Louisiana:

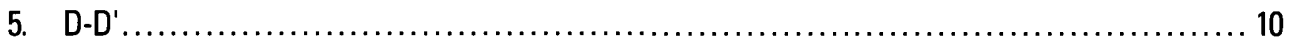

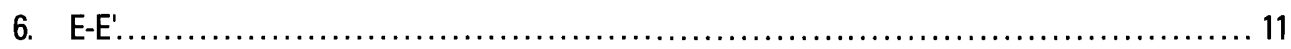

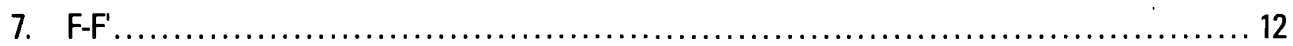

\section{Conversion Factors and Datums}

\begin{tabular}{lcl}
\hline Multiply & By & To obtain \\
\hline & & \\
inch (in.) & 25.4 & millimeter $(\mathrm{mm})$ \\
inch (in.) & 2.54 & centimeter $(\mathrm{cm})$ \\
foot (ft) & 0.3048 & meter $(\mathrm{m})$ \\
mile (mi) & 1.609 & kilometer $(\mathrm{km})$ \\
square mile $\left(\mathrm{mi}^{2}\right)$ & 0.004047 & square kilometer $\left(\mathrm{km}^{2}\right)$ \\
square mile $\left(\mathrm{mi}^{2}\right)$ & 640.0 & acre \\
foot per mile (ft/mi) & 0.1894 & meter per kilometer $(\mathrm{m} / \mathrm{km})$ \\
million gallons per day (Mgal/d) & 3785 & cubic meter per day $\left(\mathrm{m}^{3} / \mathrm{d}\right)$ \\
\hline
\end{tabular}

Temperature in degrees Celsius $\left({ }^{\circ} \mathrm{C}\right)$ can be converted to degrees Fahrenheit $\left({ }^{\circ} \mathrm{F}\right)$ as follows:

$$
{ }^{\circ} \mathrm{F}=\left(1.8 \mathrm{x}^{\circ} \mathrm{C}\right)+32
$$

Vertical coordinate information in this report is referenced to the National Geodetic Vertical Datum of 1929 (NGVD 29)--a geodetic datum derived from a general adjustment of the first-order level nets of both the United States and Canada.

Horizontal coordinate information is referenced to the North American Datum of 1927 (NAD 27). 


\title{
Hydrogeologic Maps and Sections of the "400-foot," "600-foot," and "800-foot" Sands of the Baton Rouge Area and Adjacent Aquifers in East and West Baton Rouge, East and West Feliciana, and Pointe Coupee Parishes, Louisiana
}

\author{
By Jason M. Griffith
}

\section{Abstract}

The location, altitude of the top and base, and areal extent within the study area of the Mississippi River alluvial and upland terrace aquifers, and the aquifers designated as shallow, "400-foot," "600-foot," and " 800 -foot" sands of the Baton Rouge area are shown on 12 maps and six hydrogeologic sections. Aquifers in the study area, which includes East and West Baton Rouge, East and West Feliciana, and Pointe Coupee Parishes, consist of a sequence of complexly interbedded, interconnected, lenticular, alluvial, freshwater-bearing, clayey, sandy, and graveliferous strata.

In the study area, the Mississippi River alluvial aquifer is located west of the Mississippi River floodplain boundary in Pointe Coupee and West Baton Rouge Parishes, and in the westernmost parts of West Feliciana and East Baton Rouge Parishes. The altitude of the top of the aquifer ranges from about 0 to 100 feet below National Geodetic Vertical Datum of 1929 (NGVD 29). The altitude of the base of the Mississippi River alluvial aquifer ranges from about 100 to 300 feet below NGVD 29.

The shallow sands of the Baton Rouge area are present in East Baton Rouge Parish and the southern half of West Baton Rouge Parish. The altitude of the top of the aquifer ranges from about 50 to 250 feet below NGVD 29. The altitude of the base of the aquifer ranges from about 50 feet above to 550 feet below NGVD 29.

The upland terrace aquifer is present in the northern part of the study area east of the Mississippi River flood-plain boundary. The altitude of the top of the aquifer ranges from about 100 to 300 feet above NGVD 29. The altitude of the base of the aquifer ranges from about 250 feet above to 50 feet below NGVD 29.

The "400-foot" sand of the Baton Rouge area is present in the southern half of the study area. The altitude of the top of the aquifer ranges from about 0 to 600 feet below NGVD 29. The altitude of the base of the aquifer ranges from about 50 to 750 feet below NGVD 29.

The "600-foot" sand of the Baton Rouge area is present in the southern half of the study area. The altitude of the top of the aquifer ranges from about 100 feet above to 850 feet below NGVD 29. The altitude of the base of the aquifer ranges from about 0 to 950 feet below NGVD 29.

The "800-foot" sand of the Baton Rouge area is present in the southern two-thirds of the study area. The altitude of the top of the aquifer ranges from about 150 feet above to 1,100 feet below NGVD 29. The altitude of the base of the aquifer ranges from about 0 to 1,200 feet below NGVD 29.

\section{Introduction}

Ground water constitutes a valuable and abundant natural resource in southeastern Louisiana. In East and West Baton Rouge, East and West Feliciana, and Pointe Coupee Parishes (hereinafter referred to as the five-parish area), water from many aquifers requires little treatment for potable use or industrial purposes (Stuart and others, 1994, p. 1). In 2000, about $174 \mathrm{Mgal} / \mathrm{d}$ of ground water was pumped from wells for public supply, indus- 
trial use, and power generation in the five-parish area (Sargent, 2002, table 2). Public supply use totaled about $81 \mathrm{Mgal} / \mathrm{d}$ and industrial use totaled about $83 \mathrm{Mgal} / \mathrm{d}$. In East Baton Rouge Parish alone, about $136 \mathrm{Mgal} / \mathrm{d}$ of water was pumped from aquifers.

Pumpage in the five-parish area has caused waterlevel declines in Livingston and St. Helena Parishes (Nyman and Fayard, 1978, p. 57; Tomaszewski, 1988, p. 31). Previous studies also have shown that saltwater encroachment into freshwater areas has occurred in response to pumpage (Rollo, 1969; Whiteman, 1979; Tomaszewski, 1996). Heavy pumping of ground water. in the five-parish area has caused saltwater to move northward across an east-west trending fault ${ }^{1}$. Saltwater encroachment has been detected in aquifers including the "600-foot," "1,000-foot," "1,200-foot," "1,500-foot," "2,000-foot," and "2,800-foot" sands of the Baton Rouge area in the five-parish area (Tomaszewski, 1996).

In 1998, in an effort to mitigate saltwater encroachment in the "1,500-foot" sand of the Baton Rouge area, a connector well was installed between municipal supply wells and the freshwater/saltwater interface in the "1,500-foot" sand. The connector well is screened in both the "800-foot" and "1,500-foot" sands and allows water to continuously flow downgradient from the "800-foot" sand through the well into the "1,500-foot" sand. As water continuously flows through the connector well, the potentiometric surface near the connector well will rise in the "1,500-foot" sand and fall in the "800-foot" sand (Capital Area Ground Water Conservation Commission, 2002). A rise in the potentiometric surface in the " 1,500 -foot" sand near the connector well is expected to deflect the encroaching saltwater away from the municipal supply wells. However, detailed hydrogeologic maps or sections showing the areal extent of the " 800 -foot" sand are needed to help assess the effects on water levels in the aquifer by the connector well and withdrawals from the " 800 -foot" sand at current (2004) and proposed wells.

During the past several decades, many groundwater studies have focused on one or more of the aquifers present in the five-parish area (Meyer and Turcan, 1955; Morgan, 1963; Smith, 1969; Winner and others, 1968; Whiteman, 1979; Kuniansky and others, 1989). As a result, many of the aquifers have been mapped in parts of the area. However, few of the aquifers have been mapped throughout the five-parish area. Detailed hydrogeologic maps and sections showing the location of aquifers in the five-parish area, including the "400-foot," "600-foot," and " 800 -foot" sands of the Baton Rouge area and adjacent aquifers, are needed to fully understand and manage this complex ground-water system.

In response to these needs, the U. S. Geological Survey (USGS), in cooperation with the Capital Area Ground Water Conservation Commission, began a study in 1997 to consolidate information from and build upon previous reports to create a document that illustrates the hydrogeology of the near-surface aquifers in the fiveparish area.

\section{Purpose and Scope}

This report documents the hydrogeology of the Mississippi River alluvial and upland terrace aquifers and aquifers designated as the shallow, "400-foot," "600-foot," and " 800 -foot" sands of the Baton Rouge area in southeastern Louisiana. The location, altitude of top and base, and areal extent of the aquifers are shown on 12 maps and three north-to-south and three west-toeast hydrogeologic sections. Information from previous reports and interpretations of electric logs and drillers' lithologic logs for 812 boreholes provided the basis for these maps and hydrogeologic sections. Results of this study will improve knowledge of ground-water resources and aquifer relations in southeastern Louisiana and could be relevant to similar coastal settings.

\section{Description of Study Area}

The study area (pl. 1) extends across about 2,000 $\mathrm{mi}^{2}$ and includes East and West Baton Rouge, East and West Feliciana, and Pointe Coupee Parishes (Calhoun and Frois, 1997, p. 153). About half a million people live within the area, with the largest concentration in East Baton Rouge Parish (Calhoun and Frois, 1997, p. 153). With the exception of the City of Baton Rouge and surrounding suburbs, much of the area is used for rural and agricultural purposes.

The economy of the study area is dependent or partially dependent on the ground-water resources in the region. Baton Rouge and several petrochemical and industrial facilities are located along the Mississippi River. The large concentration of petrochemical manufacturers along the Mississippi River provides important revenue for the economy (See Calhoun and Frois, 1997, p. 205-268, 350) .

The climate is warm and temperate with high humidity and frequent rain. At Baton Rouge, the climate is subtropical, warm, and temperate with an average annual temperature of $20^{\circ} \mathrm{C}\left(68^{\circ} \mathrm{F}\right)$ and an average

\footnotetext{
${ }^{1} \mathrm{~A}$ fault is a fracture or fracture zone along which displacement has occurred (Bates and Jackson, 1984, p. 178).
} 
annual rainfall of about 60 in (National Oceanic and Atmospheric Administration, 1995, p. 5, 8).

\section{Methods of Study}

For this investigation, information from previous reports, electric logs, and drillers' lithologic logs were consolidated to show the shallow hydrogeology in the study area. Most of the hydrogeology shown in this report was based on interpretations of selected waterwell logs throughout the area. Petroleum test-well logs provided coverage for areas where water-well logs were unavailable. Data used for this project (including electric-log data) are contained in files at the USGS office in Baton Rouge, Louisiana.

The location and altitude of sands ${ }^{2}$ and clays ${ }^{3}$ underlying the study area were determined using singlepoint resistance, spontaneous potential, short-normal resistivity, medium induction resistivity, and drillers' lithologic logs. Other logs used for interpretive analyses were the spherically-focused induction resistivity, shortguard resistivity, and induction resistivity. Generally, sands and clays less than $20 \mathrm{ft}$ thick are considered thin or missing and are excluded from the hydrogeologic maps and sections.

The location of the faults shown in this report are based on information from previous reports that document the faults at a few specific sites in the study area. In areas where information about the faults is sparse, the location of the faults, as shown on the maps and sections in this report, are based on information from previous studies of nearby areas. Otherwise, affirming the location of the faults throughout the study area are beyond the scope of this investigation. Therefore, the faults are dashed where approximate and queried where probable on the maps and sections in this report. (See Durham and Peeples, 1956; Murray, 1961, p. 188-191; Meyer and Rollo, 1965; Winner and others, 1968, p. 10-12; Rollo, 1969, p. 11; Whiteman, 1979, p. 3, 4; Hanor, 1982, p. 237-245; Smoot, 1988; and McCulloh, 1991, p. 1-20.)
Using previous reports as a baseline, hydrogeologic units (aquifers ${ }^{4}$ and confining units ${ }^{5}$ ) were correlated from $\log$ to $\log$. For any $\log$, the altitude above or below NGVD 29 to the top of the shallowest sand in a hydrogeologic interval was picked as the top of the hydrogeologic unit, and similarly, the base of the deepest sand in the hydrogeologic interval was picked as the base of the hydrogeologic unit. Picks from logs outside the study area provided peripheral data necessary for accurate interpolation of the top and base of hydrogeologic units at the boundaries of the study area. Correlation of hydrogeologic units between logs was determined using several assumptions: the least complex correlation between $\operatorname{logs}$ is the most probable; hydrogeologic unit attitudes are probably similar to vertically adjacent unit attitudes; and prospective correlations that contradict the preceding assumptions require substantial evidence (Griffith, 2003, p. 5).

The picks for the altitude of the top and base of the hydrogeologic units from each log were entered into a data base for analysis in a geographic information system (GIS). For this report, the picks were analyzed using Viewlog (version 3), a GIS software that provides tools for the management and interpretation of well log data and three-dimensional modelling and visualization of hydrogeologic units. The contours for each map showing the top or base of a hydrogeologic unit were generated from the picks using the full-kriging tool in the Viewlog statistically-based interpolation package (Viewlog Systems, 2004, p. 347). Kriging was particularly applicable for making estimates in areas where few picks exist (Dunlap and Spinazola, 1984, p. 5). Contours generated by kriging were manually adjusted in some areas to agree with points where picks were recorded.

Except for the Mississippi River alluvial aquifer and the shallow sands of the Baton Rouge area, kriging with the Viewlog fault-kriging option (Viewlog Systems, 2004, p. 347) generated separate maps on each side of the faults using data for the respective side of the fault. In some areas where log data were unavailable the contours generated by the Viewlog fault-kriging option were

\footnotetext{
${ }^{2}$ For this report, a sand is defined as a relatively permeable lithologic unit mostly composed of material ranging from fine sand to gravel.

${ }^{3}$ For this report, a clay is defined as a relatively impermeable lithologic unit mostly composed of material ranging from solid clay to sandy and silty clay.

${ }^{4}$ An aquifer is defined as a hydrogeologic unit composed of sand or a series of interconnected sands that is sufficiently permeable to conduct ground water and to yield economically substantial quantities of water to wells and springs (modified from Bates and Jackson, 1984, p. 26).

${ }^{5} \mathrm{~A}$ confining unit is defined as a hydrogeologic unit composed of clay or a series of clays that impedes or obstructs groundwater flow (modified from Bates and Jackson, 1984, p. 104)
} 
manually adjusted to reflect the probable offset indicated by data in nearby areas and previous research (Durham and Peeples, 1956, p. 65; Murray, 1961, p. 190; Meyer and Rollo, 1965, fig. 3; Winner and others, 1968, p. 10-12; Rollo, 1969, p. 11; Whiteman, 1979, p. 4; Hanor, 1982, p. 244; McCulloh, 1991, p. 18-20; and Griffith, 2003, p. 12.)

\section{Acknowledgments}

The author would like to thank the many people who helped produce this report. All have given their ideas obligingly and have contributed substantially to a better understanding of the hydrogeology of the study area. Recognition is given to Don C. Dial, Chairman, and members of the Capital Area Ground Water Conservation Commission for support and assistance provided for the study. A special thanks is given to Louisiana water-well drillers and loggers for generating geophysical logs. Also, thanks are given to the Louisiana Department of Natural Resources for providing access to their collection of petroleum test-well geophysical logs.

\section{Hydrogeologic Maps And Sections}

There are 14 aquifers in the study area (fig. 1) that consist of a sequence of complexly interbedded, interconnected, lenticular (lens shaped), alluvial, freshwaterbearing, clayey, sandy, and graveliferous strata. The sediments in the study area compose the Southern Hills regional aquifer system. The hydrogeologic units in the Southern Hills regional aquifer system form a wedge that dips and thickens to the south and southwest toward the Gulf of Mexico and Mississippi River alluvial valley. Generally, clayey confining units pinch out (disappear) updip, and older, deeper aquifers coalesce with younger, shallower surficial aquifers. (See Griffith, 2003, p. 8.)

Aquifers in the Southern Hills regional aquifer system have been grouped into systems which are named in accordance with their correlative units in central and southwestern Louisiana, west of the Mississippi River. The Chicot equivalent aquifer system is the shallowest of these systems. The Mississippi River alluvial and the upland terrace aquifers, and the shallow, " 400 -foot" and "600-foot" sands of the Baton Rouge area compose the Chicot equivalent aquifer system in the study area.

Below the Chicot equivalent aquifer system is the Evangeline equivalent aquifer system. In the study area, the "800-foot" sand is the shallowest aquifer in the Evangeline equivalent aquifer system.

The Tepetate-Baton Rouge fault system ${ }^{6}$ extends from southeastern Louisiana through East Baton Rouge, West Baton Rouge, and Pointe Coupee Parishes into southwestern Louisiana. The system is composed of a series of east-to-west trending normal faults, along which the southern block has moved downward relative to the northern block. These are reactivated growth faults that dip to the south and show increasing displacement with depth. There are at least two active faults in the system (pl. 1). The Tepetate fault (locally known as the Denham Springs-Scotlandville fault in the study area) and Baton Rouge fault consist of a somewhat discontinuous network of parallel and en echelon ${ }^{7}$ fault sets $^{8}$. (See Durham and Peeples, 1956; Murray, 1961, p. 188-191; Meyer and Rollo, 1965; Winner and others, 1968, p. 10-12; Rollo, 1969, p. 11; Whiteman, 1979, p. 3, 4; Hanor, 1982, p. 237-245; Smoot, 1988;

McCulloh, 1991, p. 1-20; and Griffith, 2003, p. 6.)

Generally, fault displacement in the study area increases with depth and is often indiscernible near ground surface such that aquifers maintain integrity across a fault. However, faulted sands can terminate abruptly against a clay or other confining unit at a fault. Also, displacement along a fault plane can result in the juxtaposition of sand units north of a fault with stratigraphically overlying sand units south of the fault. The displacement of aquifers at the Tepetate fault ranges from a few feet near ground surface to about $35 \mathrm{ft}$ at an altitude of $800 \mathrm{ft}$ below NGVD 29. The displacement of aquifers at the Baton Rouge fault, ranges from about $20 \mathrm{ft}$ near ground surface to about $225 \mathrm{ft}$ at an altitude of 1,200 ft below NGVD 29. (See Durham and Peeples, 1956, p. 65; Murray, 1961, p. 190; Winner and others, 1968, p. 10-12; Rollo, 1969, p. 11; Whiteman, 1979, p. 3, 4, 7; Roland and others, 1981, p. 6, 7, 9; Hanor, 1982, p. 237-245; Smoot, 1988; McCulloh, 1991, p. 1-20; Tomaszewski, 1996; and Griffith, 2003, p. 12.)

\footnotetext{
${ }^{6} \mathrm{~A}$ fault system consists of two or more interconnecting fault sets (Bates and Jackson, 1984, p. 179).

${ }^{7}$ A group of subparallel, closely-spaced, step-like, overlapping or staggered arrangement of short faults that collectively form a linear fault zone (modified from Bates and Jackson, 1984, p. 179).

${ }^{8} \mathrm{~A}$ fault set is composed of a group of faults that are parallel or nearly so, and are related to a particular deformational episode (Bates and Jackson, 1984, p. 179).
} 


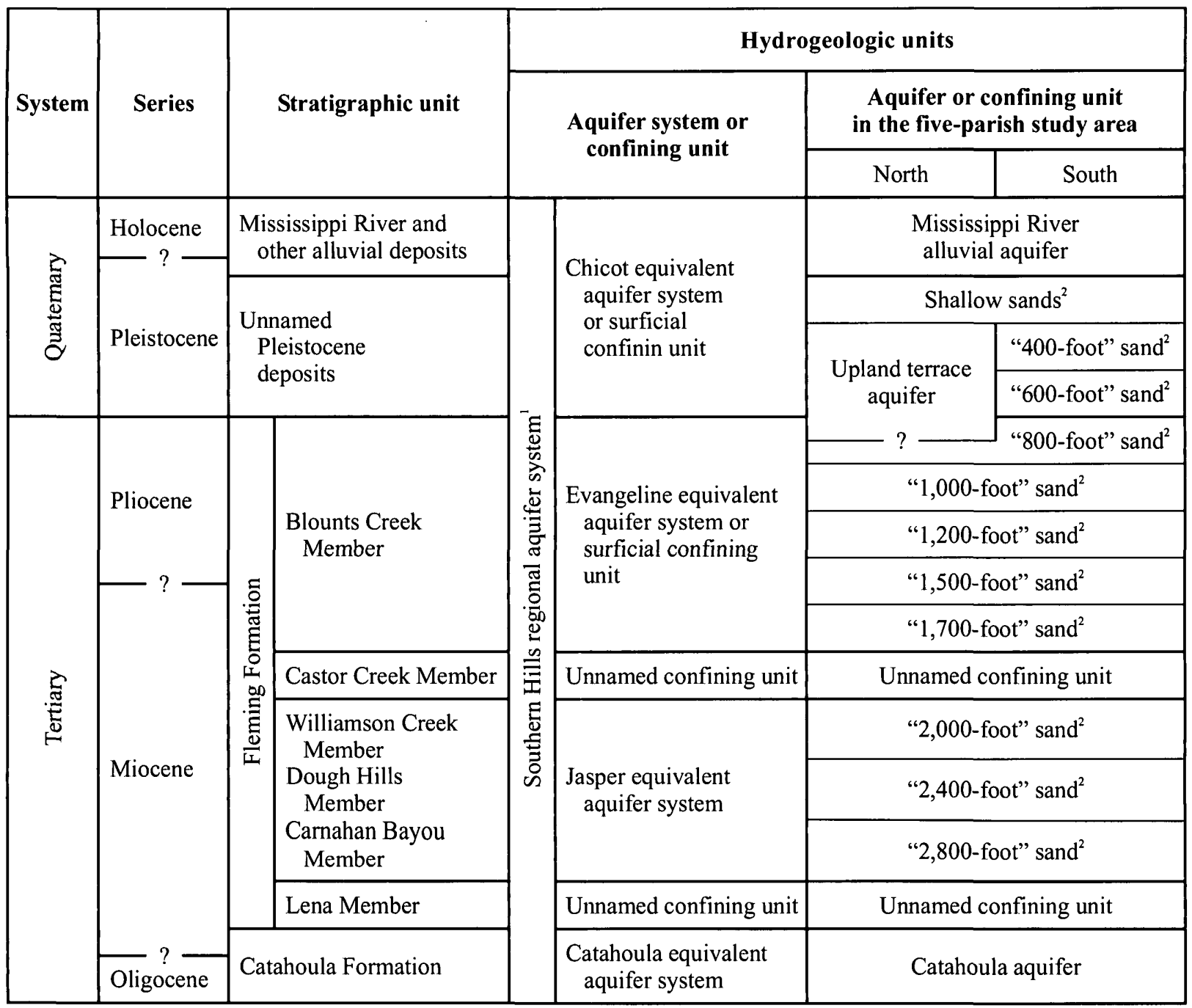

'Buono, 1983.

${ }^{2} \mathrm{O}$ the Baton Rouge area.

Figure 1. Hydrogeologic units in East and West Baton Rouge, East and West Feliciana, and Pointe Coupee Parishes, southeastern Louisiana (modified from Lovelace and Lovelace, 1995, fig. 1).

Delineation and correlation of aquifers in the study area is somewhat uncertain. Throughout the study area, lenticular shaped deposits abruptly change from sand to clay, and many aquifers merge with overlying and underlying aquifers. Vertical offset of aquifers along the numerous faults varies in the study area. Mapping local variations in the hydrogeologic units, such as those created by the filling of incised channels, was beyond the scope of the investigation.

\section{Mississippi River Alluvial Aquifer}

In the study area, the Mississippi River alluvial aquifer is located southwest of the Mississippi River flood-plain boundary in Pointe Coupee and West Baton
Rouge Parishes, and in the westernmost parts of West Feliciana and East Baton Rouge Parishes (pls. 2, 3; figs. 2-7). The aquifer extends beyond the study area into northern and southern Louisiana. The aquifer is a largely uninterrupted mass of sand (Saucier, 1994, v. 1, p. 306) and constitutes an enormous fresh ground-water resource in southeastern Louisiana.

In the study area, although the top of the Mississippi River alluvial aquifer has some local undulations, it is relatively flat and has no discernible dip (pl. 2). The altitude of the top of the Mississippi River alluvial aquifer ranges from about 0 to $100 \mathrm{ft}$ below NGVD 29.

The base of the Mississippi River alluvial aquifer is defined as the base of the first gravel (Winner and others, 1968, p. 16). Similar to the top of the Mississippi 
River alluvial aquifer, the base is relatively flat and has no discernible dip (pl. 3). The altitude of the base of the Mississippi River alluvial aquifer ranges from about 100 to $300 \mathrm{ft}$ below NGVD 29. In one area of northwest West Baton Rouge Parish and southeast Pointe Coupee Parish, the altitude of the base of the aquifer is deeper than $300 \mathrm{ft}$ below NGVD 29.

\section{Shallow Sands of the Baton Rouge Area}

The shallow sands of the Baton Rouge area are present in the southern half of West Baton Rouge Parish and most of East Baton Rouge Parish (pls. 4, 5;

figs. $3,4,6,7)$. The aquifer is thin or missing in a large area that extends from Baker south through the city limits of Baton Rouge.

Within the near-surface interval of the shallow sands, clay and silt dominate, and the discontinuous, lenticularly shaped sand deposits may or may not be hydraulically connected (Kuniansky and others, 1989, p. 11). West of the Mississippi River flood-plain boundary, the shallow sands merge with the overlying Mississippi River alluvial aquifer and form a single hydrogeologic unit (figs. 4, 6) that is $510 \mathrm{ft}$ thick in some places (Whiteman, 1972, p. 15-17, 18-20; Kuniansky and others, 1989 , p. 10, 11).

The altitude of the top of the shallow sands ranges from about $50 \mathrm{ft}$ above to $250 \mathrm{ft}$ below NGVD 29 (pl. 4). The top of the shallow sands dips to the south-southwest at about $16 \mathrm{ft} / \mathrm{mi}$.

The base of the shallow sands dips to the southsouthwest at about $27 \mathrm{ft} / \mathrm{mi}$. The altitude of the base of the shallow sands ranges from about $50 \mathrm{ft}$ above NGVD 29, near Port Hudson, to $550 \mathrm{ft}$ below NGVD 29, south of Addis (pl. 5).

\section{Upland Terrace Aquifer}

The upland terrace aquifer is present in the northern part of the study area east of the Mississippi River floodplain boundary (pls. 6, 7; figs. 2, 6, 7). The aquifer extends from the northern boundary of the study area south into northern East Baton Rouge Parish. From the Mississippi River flood-plain boundary it extends through West and East Feliciana Parishes, beyond the study area east, into southeastern Louisiana and north, into southwestern Mississippi.

The upland terrace aquifer is a broad, generally continuous near-surface aquifer. In some areas the aquifer is discontinuous due to intervening recent stream deposits. The upland terrace aquifer coalesces with many of the
- aquifers in the study area including the " 400 -foot," "600-foot," and "800-foot" sands of the Baton Rouge area. Subsequently, precipitation that infiltrates the upland terrace aquifer is the primary source of recharge for aquifers in the region (Morgan, 1963, p. 11-13; Buono, 1983, p. 24; and Griffith 2003, p. 6).

In the study area, the top of the upland terrace aquifer dips to the south-southwest at about $10 \mathrm{ft} / \mathrm{mi}$ and varies with changes in surface topography (pl. 6). The altitude of the top of the aquifer ranges from about 100 to $300 \mathrm{ft}$ above NGVD 29.

The base of the upland terrace aquifer dips to the south-southwest at about $15 \mathrm{ft} / \mathrm{mi} \mathrm{(pl.} \mathrm{7).} \mathrm{The} \mathrm{altitude} \mathrm{of}$ the base of the aquifer in the study area ranges from about $250 \mathrm{ft}$ above to $50 \mathrm{ft}$ below NGVD 29 .

\section{"400-Foot" Sand of the Baton Rouge Area}

The " 400 -foot" sand of the Baton Rouge area is present in most of the southern half of the study area including most of East and West Baton Rouge Parishes and a small area in southern Pointe Coupee Parish (pls. 8, 9; figs. 3-7). The altitude of the top of the " 400 -foot" sand ranges from about 0 to $600 \mathrm{ft}$ below NGVD 29 (pl. 8). The top of the " 400 -foot" sand dips to the south at about $24 \mathrm{ft} / \mathrm{mi}$. The altitude of the base of the "400-foot" sand ranges from about 50 to $750 \mathrm{ft}$ below NGVD 29 (pl. 9). The base of the " 400 -foot" sand dips to the south at about $27 \mathrm{ft} / \mathrm{mi}$.

\section{"600-Foot" Sand of the Baton Rouge Area}

The " 600 -foot" sand of the Baton Rouge area is present in most of the southern half of the study area (pls. 10, 11; figs. 2-7). East of the Mississippi River flood-plain boundary, the northern limit of the "600-foot" sand is near the town of Ethel. West of the flood-plain boundary, the northern limit of the aquifer is near the town of New Roads. In several areas in East and West Baton Rouge Parishes the "600-foot" sand is thin or missing.

The altitude of the top of the " 600 -foot" sand ranges from about $100 \mathrm{ft}$ above NGVD 29, south of Clinton to about $850 \mathrm{ft}$ below NGVD 29, in southern East and West Baton Rouge Parishes (pl. 10). The top of the "600-foot" sand dips to the south-southwest at about $29 \mathrm{ft} / \mathrm{mi}$.

The altitude of the base of the "600-foot" sand ranges from about 0 to $950 \mathrm{ft}$ below NGVD 29 (pl. 11). The base of the " 600 -foot" sand dips to the south-southwest at about $29 \mathrm{ft} / \mathrm{mi}$. 


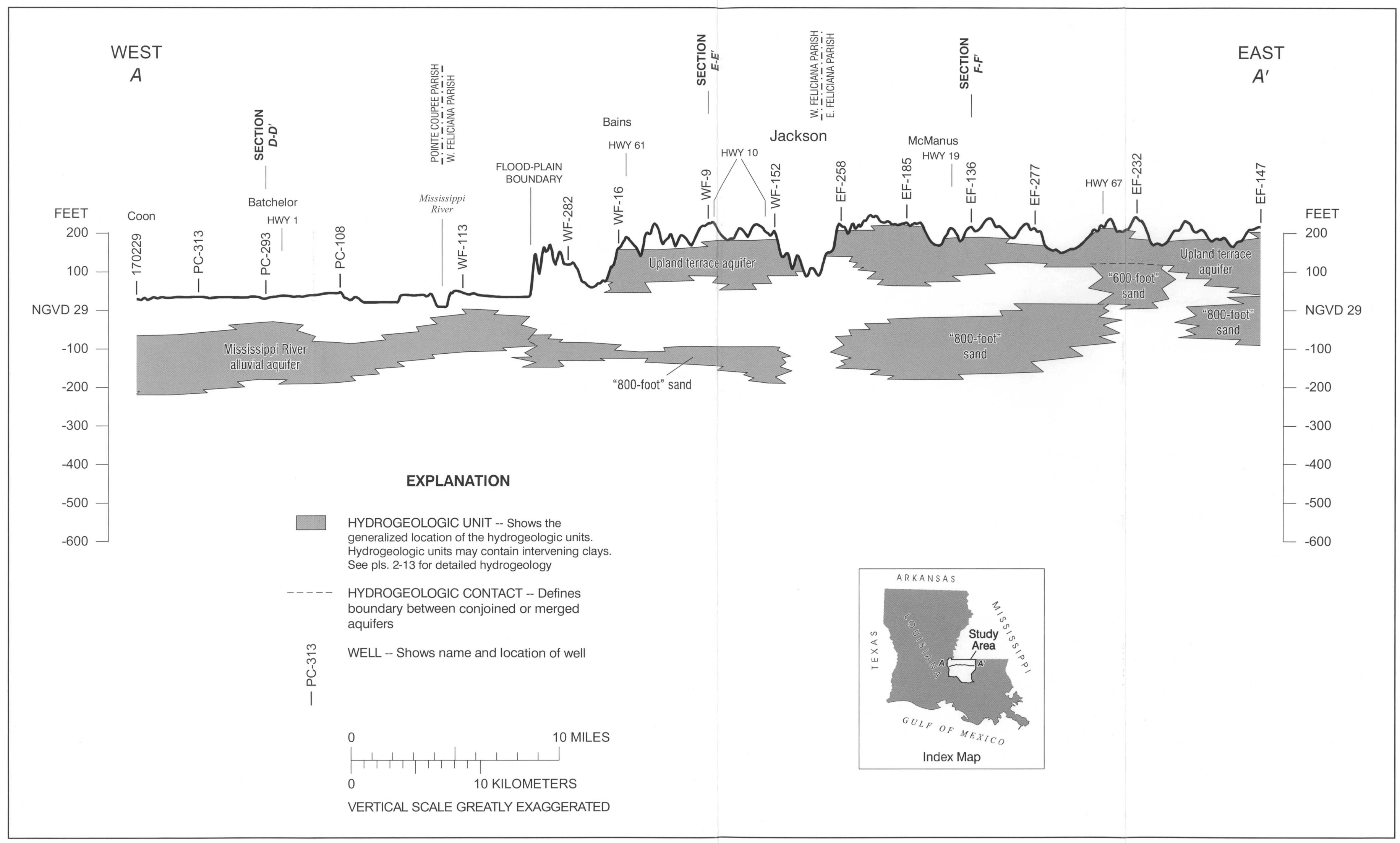

Figure 2. West-to-east hydrogeologic section A-A' in East and West Baton Rouge, East and West Feliciana, and Pointe Coupee Parishes, sotheastern Louisiana. 


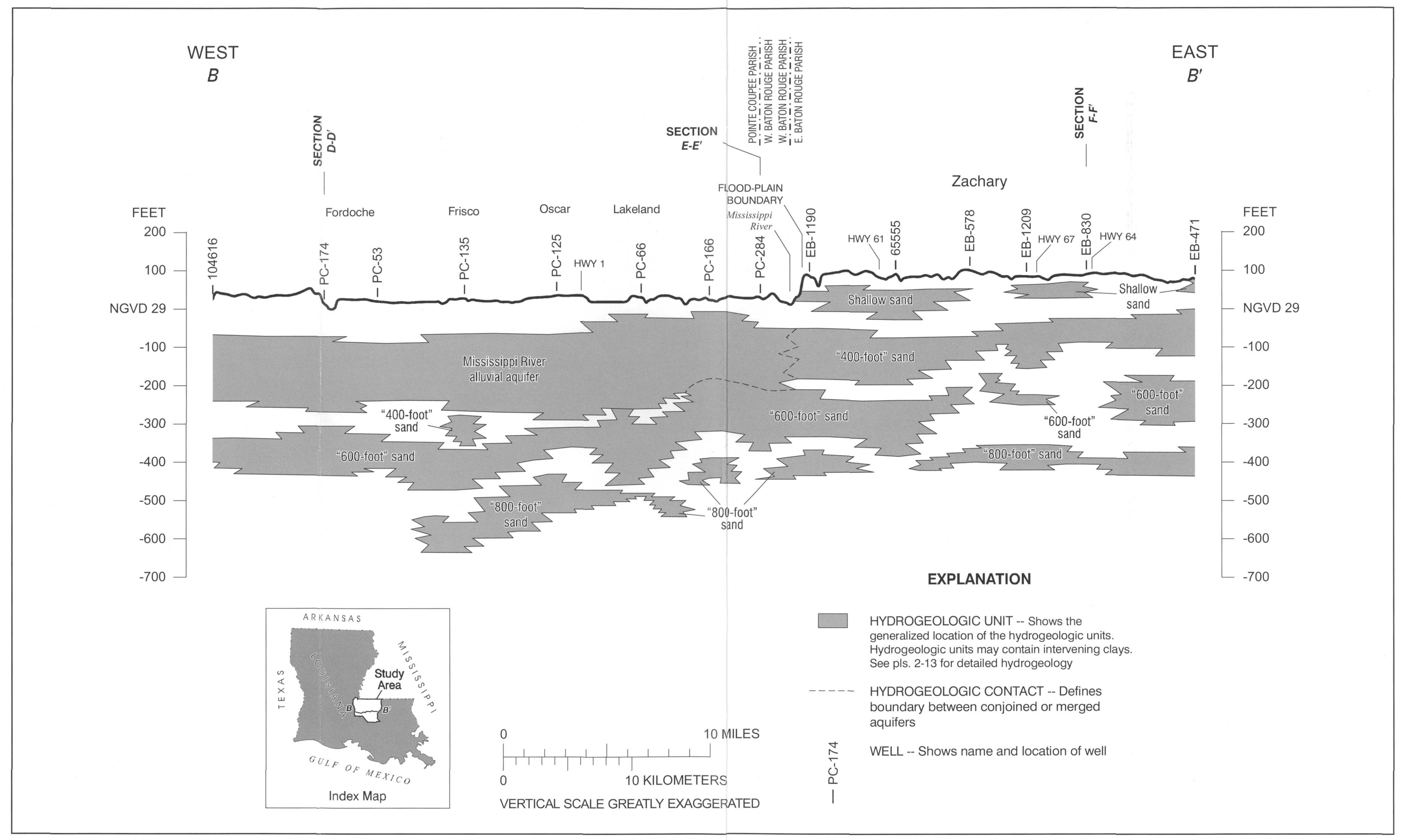

Figure 3. West-to-east hydrogeologic section B-B' in East and West Baton Rouge, East and West Feliciana, and Pointe Coupee Parishes, southeastern Louisiana. 


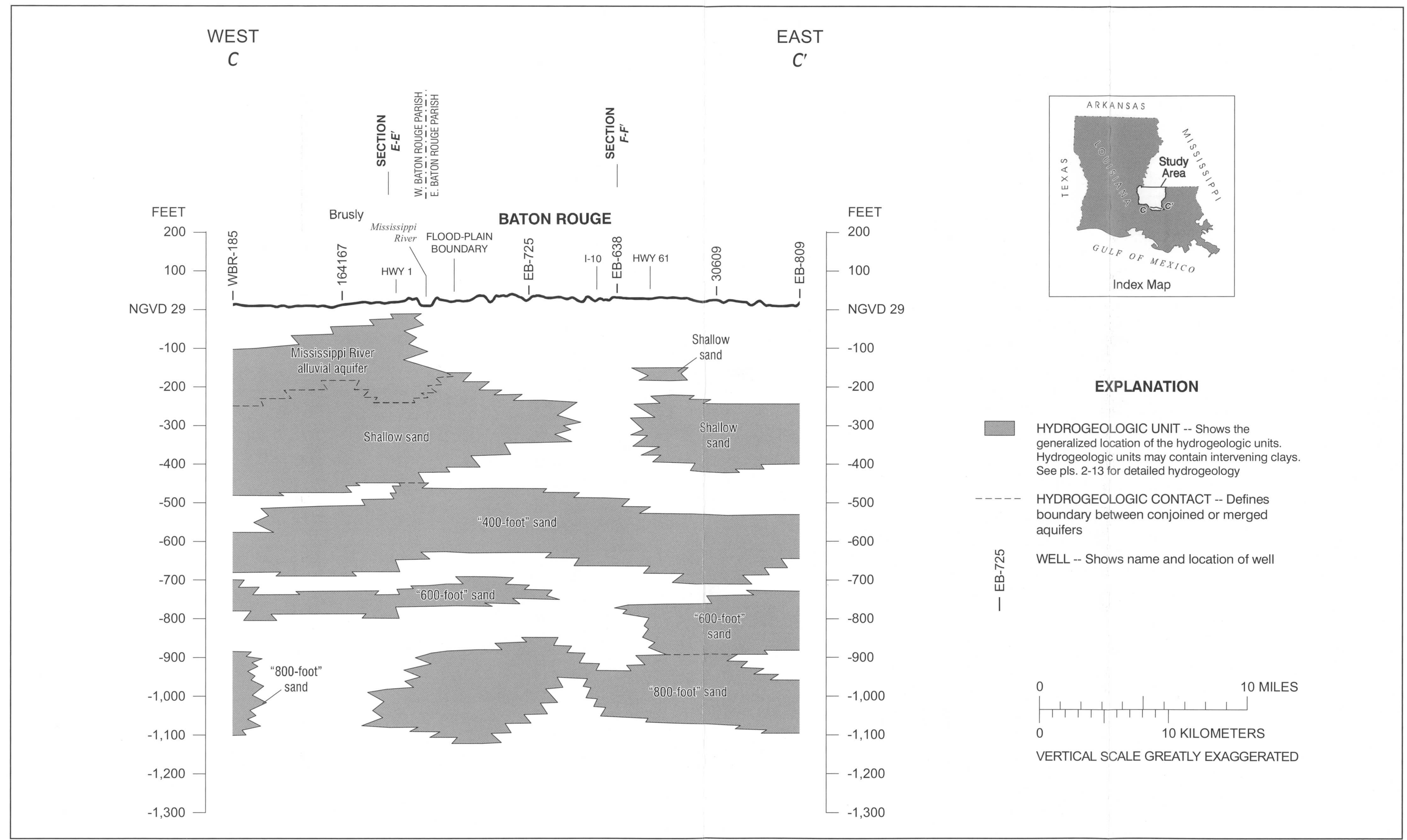

Figure 4. West-to-east hydrogeologic section C-C' in East and West Baton Rouge, East and West Feliciana, and Pointe Coupee Parishes, southeastern Louisiana. 
10 Hydrogeologic Maps and Sections of the "400- 600- and 800-foot," Sands of the Baton Rouge Area

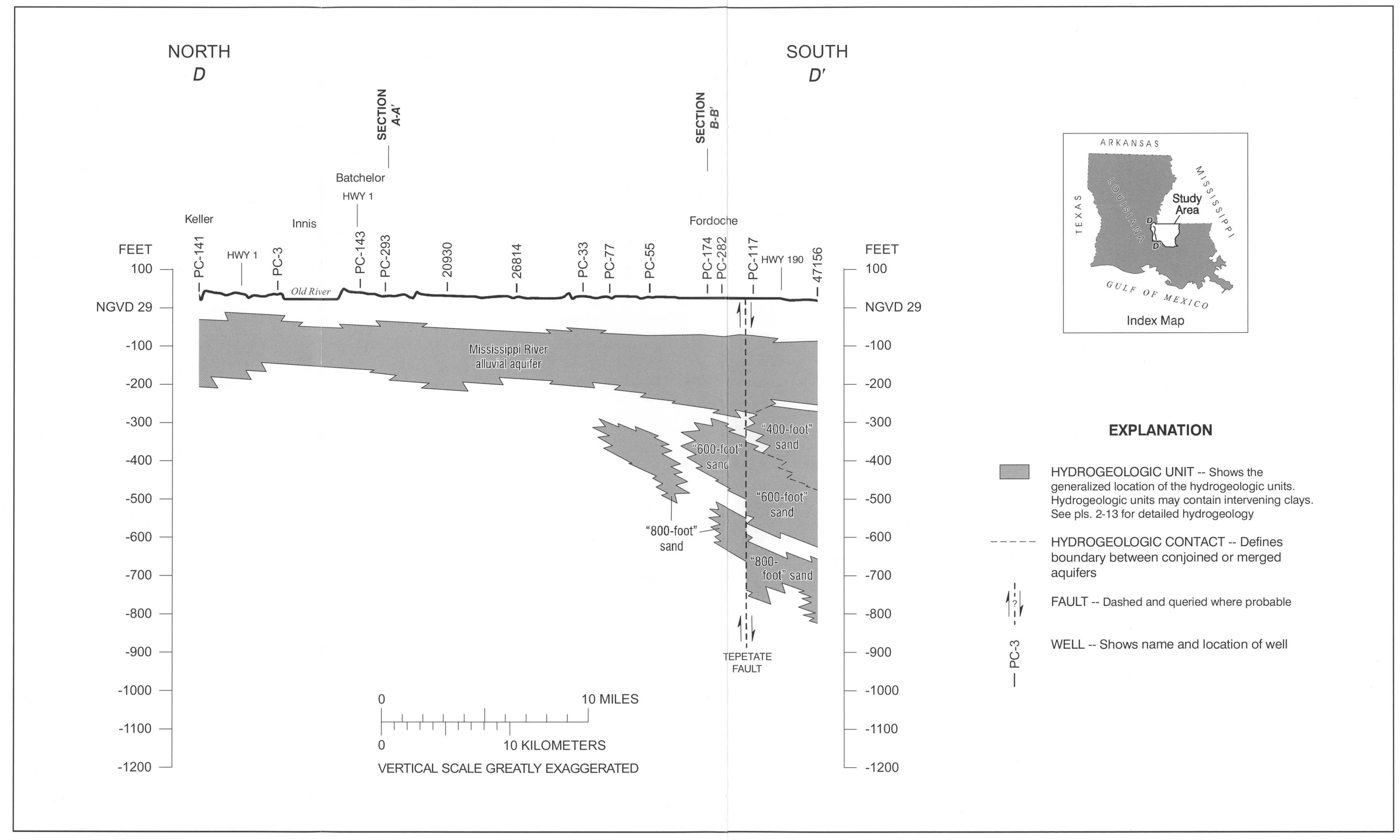

Figure 5. North-to-south hydrogeologic section D-D' in East and West Baton Rouge, East and West Feliciana, and Pointe Coupee Parishes, southeastern Louisiana. 


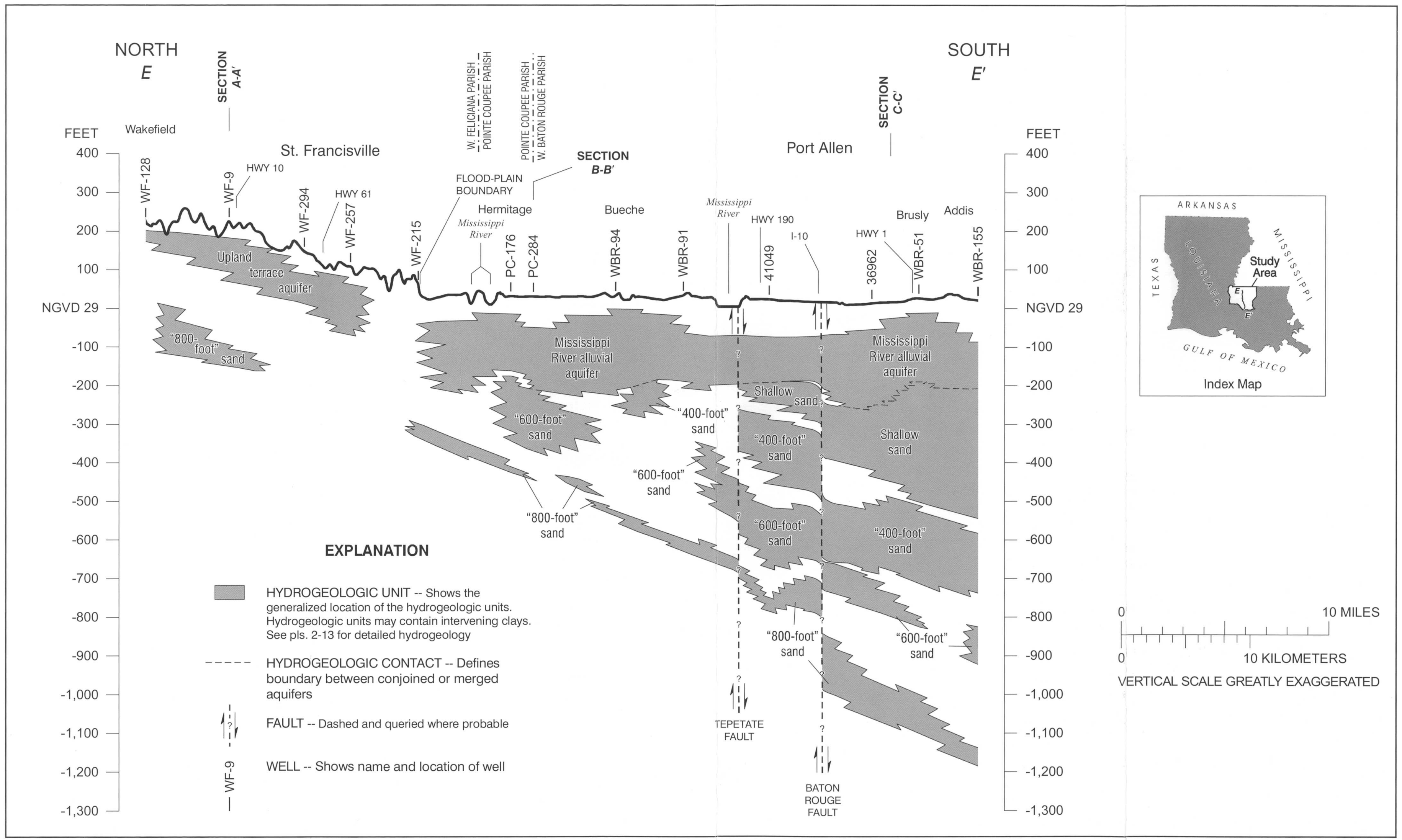

Figure 6. North-to-south hydrogeologic section E-E' in East and West Baton Rouge, East and West Feliciana, and Pointe Coupee Parishes, southeastern Louisiana. 


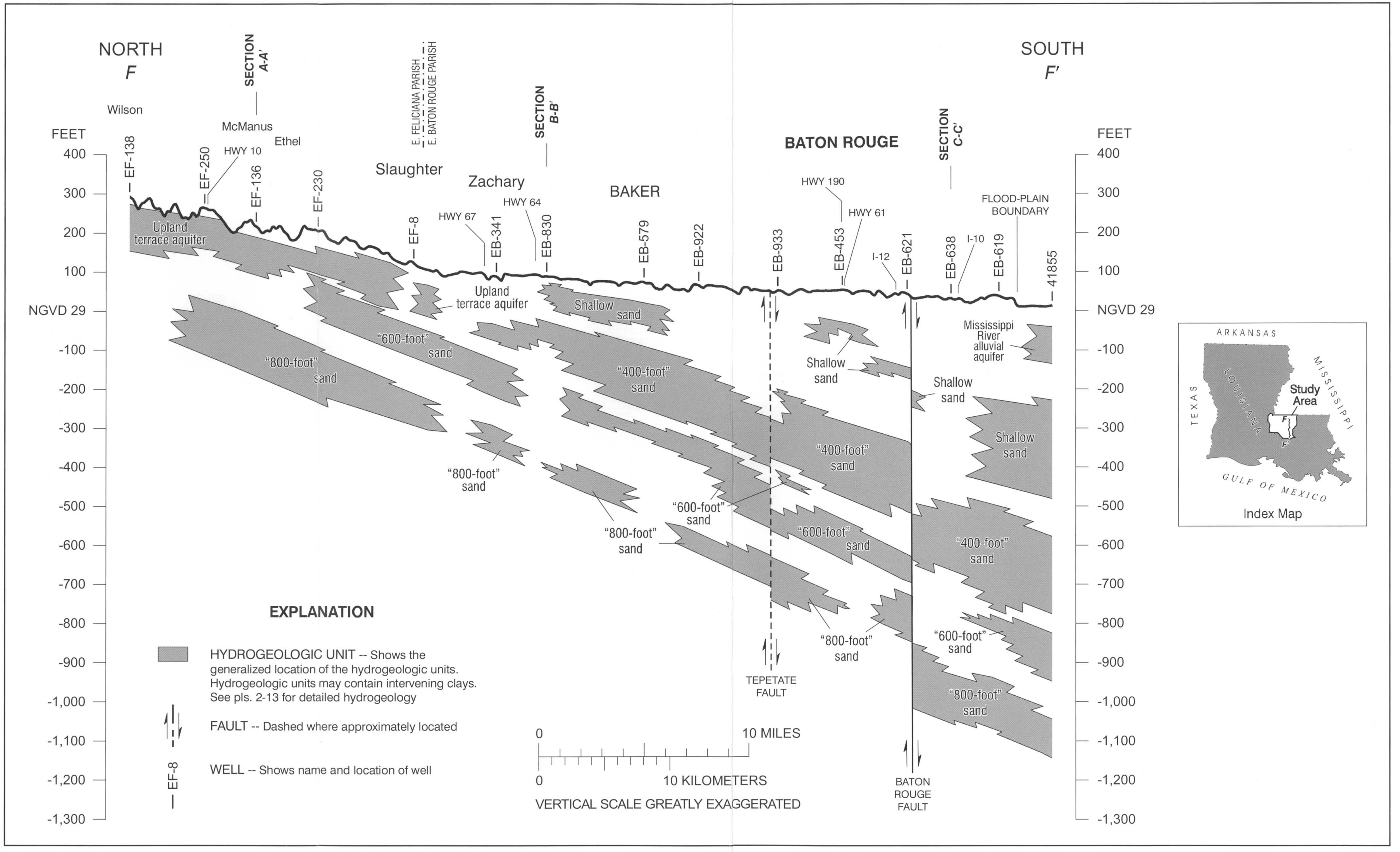




\section{"800-Foot" Sand of the Baton Rouge Area}

The "800-foot" sand of the Baton Rouge area is present in most of the southern two-thirds of the study area (pls. 12, 13; figs. 2-7). East of the Mississippi River flood-plain boundary the northern limit of the " 800 -foot" sand is at Clinton and Wakefield. West of the flood-plain boundary the northern limit of the aquifer is near

St. Francisville and Melville. Every parish in the study area includes areas where the aquifer is thin or missing. The " 800 -foot" sand is thin or missing in a large area that extends through central West Baton Rouge Parish from Bueche to Addis.

The altitude of the top of the " 800 -foot" sand ranges from about $150 \mathrm{ft}$ above NGVD 29, in northeastern East Feliciana Parish to about 1,100 ft below NGVD 29, in southern East and West Baton Rouge Parishes (pl. 12). The top of the "800-foot" sand dips to the south at about $32 \mathrm{ft} / \mathrm{mi}$.

The altitude of the base of the " 800 -foot" sand ranges from about 0 to $1,200 \mathrm{ft}$ below NGVD 29 (pl. 13). The base of the " 800 -foot" sand dips to the south at about $29 \mathrm{ft} / \mathrm{mi}$.

\section{Summary}

The location, altitude of the top and base, and areal extent of the Mississippi River alluvial and upland terrace aquifers, and the aquifers designated as shallow, " 400 -foot," "600-foot" and " 800 -foot" sands in the study area are shown on 12 maps and six hydrogeologic sections. Aquifers in East and West Baton Rouge, East and West Feliciana, and Pointe Coupee Parishes consist of a sequence of complexly interbedded, interconnected, lenticular (lens shaped), alluvial, freshwater-bearing, clayey, sandy, and graveliferous strata.

The Tepetate-Baton Rouge fault system extends through East and West Baton Rouge Parishes and Pointe Coupee Parish and is composed of a series of east-towest trending normal faults that include the Tepetate and Baton Rouge faults. The displacement of aquifers at the Tepetate fault ranges from a few feet near ground surface to about 35 feet at an altitude of 800 feet below National Geodetic Vertical Datum of 1929 (NGVD 29 ). The displacement of aquifers at the Baton Rouge fault ranges from about 20 feet near ground surface to about 225 feet at an altitude of 1,200 feet below NGVD 29.

In the study area, the Mississippi River alluvial aquifer is located southwest of the Mississippi River flood-plain boundary in Pointe Coupee and West Baton Rouge Parishes, and in the westernmost parts of West Feliciana and East Baton Rouge Parishes. The top of the aquifer is relatively flat at an altitude that ranges from 0 to 100 feet below NGVD 29. The base of the Mississippi River alluvial aquifer is relatively flat at an altitude that ranges from 100 to 300 feet below NGVD 29.

The shallow sands of the Baton Rouge area are present in the southern half of West Baton Rouge Parish and most of East Baton Rouge Parish. The top of the aquifer dips to the south-southwest at about 16 feet per mile at an altitude that ranges from about 50 feet above to 250 feet below NGVD 29. The base of the aquifer dips to the south-southwest at about 27 feet per mile at an altitude that ranges from about 50 feet above to 550 feet below NGVD 29.

The upland terrace aquifer is present in the northern part of the study area east of the Mississippi River floodplain boundary. The upland terrace aquifer is a near-surface aquifer that coalesces with and is a source of recharge for the " 400 -foot," "600-foot," and "800-foot" sands of the Baton Rouge area. The top of the aquifer dips to the south-southwest at about 10 feet per mile at an altitude that ranges from about 100 to 300 feet above NGVD 29. The base of the aquifer dips to the southsouthwest at about 15 feet per mile at an altitude that ranges from about 250 feet above to 50 feet below NGVD 29.

The "400-foot" sand of the Baton Rouge area is present in most of the southern half of the study area. The top of the aquifer dips to the south at about 24 feet per mile at an altitude that ranges from about 0 to 600 feet below NGVD 29. The base of the aquifer dips to the south at about 27 feet per mile at an altitude that ranges from about 50 to 750 feet below NGVD 29 .

The "600-foot" sand of the Baton Rouge area is present in most of the southern half of the study area. The top of the aquifer dips to the south-southwest at about 29 feet per mile at an altitude that ranges from 100 feet above to 850 feet below NGVD 29. The base of the aquifer dips to the south-southwest at about 29 feet per mile at an altitude that ranges from about 0 to 950 feet below NGVD 29.

The " 800 -foot" sand of the Baton Rouge area is present in most of the southern two-thirds of the study area. The top of the aquifer dips to the south at about 32 feet per mile at an altitude that ranges from about 150 feet above to 1,100 feet below NGVD 29. The base of the aquifer dips to the south at about 29 feet per mile at an altitude that ranges from about 0 to 1,200 feet below NGVD 29. 


\section{Selected References}

Bates, R.L., and Jackson, J.A., eds., 1984, Dictionary of geological terms (3d ed.): New York, Doubleday, $571 \mathrm{p}$.

Boniol, D.P., comp., 1988, Recharge potential of Louisiana aquifers: Baton Rouge, La., Louisiana Geological Survey, 1 sheet.

Boniol, D.P., Autin, W.J., and Hanson, B.C., 1988, Recharge potential of Louisiana aquifers--A supplement to the State aquifer recharge map and atlas plates: Baton Rouge, La., Louisiana Geological Survey Open-File Series 88-07, $50 \mathrm{p}$.

Buffler, R.T., 1991, Early evolution of the Gulf of Mexico basin, in Goldthwaite, Duncan, ed., Introduction to Central Gulf Coast geology: New Orleans, La., New Orleans Geological Society, p. 1-15.

Buono, Anthony, 1983, The Southern Hills regional aquifer system of southeastern Louisiana and southwestern Mississippi: U.S. Geological Survey WaterResources Investigations Report 83-4189, 38 p.

Calhoun, Milburn, and Frois, Jeanne, eds., 1997, Louisiana almanac (1997-98 ed.): Gretna, La., Pelican Publishing Company, $695 \mathrm{p}$.

Capital Area Ground Water Conservation Commission, 2002, Newsletter: Baton Rouge, La., Capital Area Ground Water Conservation Commission, v. 27, no. 3, 4 p.

Compton, R.R., 1985, Geology in the field: New York, John Wiley and Sons, 398 p.

Dunlap, L.E., and Spinazola, J.M., 1984, Interpolating water-table altitudes in west-central Kansas using kriging techniques: U.S. Geological Survey WaterSupply Paper 2238, 19 p.

Durham, C.O., Jr., and Peeples, E.M., III, 1956, Pleistocene fault zone in southeastern Louisiana [abs.]: New Orleans, La., Transactions of the Gulf Coast Association of Geological Societies, v. 6, p. 65-66.

Fisk, H.N., 1944, Geological investigation of the alluvial valley of the lower Mississippi River: Vicksburg, Miss., War Department, Corps of Engineers, U.S. Army, 70 p.

Fisk, H.N., Richards, H.G., Brown, C.A., and Steere, W.C., 1938, Contributions to the Pleistocene history of the Florida Parishes of Louisiana: Department of Conservation, Louisiana Geological Survey Geological Bulletin no. 12, 137 p.

Griffith, J.M., 2003, Hydrogeologic framework of southeastern Louisiana: Louisiana Department of Transportation and Development Water Resources Technical Report no. 72, 21 p., 18 pl.
Hanor, J.S., 1982, Reactivation of fault movement, Tepetate fault zone, south central Louisiana, in Transactions of the Gulf Coast Association of Geological Societies: Gulf Coast Association of Geological Societies, v. 32, p. 237-245.

Harder, A.H., Sauer, V.B., and Broussard, W.L., 1968, Water resources of the Lettsworth-Innis-Batchelor area, Pointe Coupee Parish, Louisiana: Department of Conservation, Louisiana Geological Survey, and Louisiana Department of Public Works Water Resources Pamphlet no. 21, 28 p.

Kazmann, R.G., 1970, The present and future groundwater supply of the Baton Rouge area: Baton Rouge, La., Louisiana State University, Louisiana Water Resources Research Institute Bulletin 5, 44 p.

Keys, W.S., 1990, Borehole geophysics applied to ground-water investigations: U.S. Geological Survey Techniques of Water-Resources Investigations, book 2, chap. E1, 150 p.

Keys, W.S., and MacCary, L.M., 1971, Application of borehole geophysics to water-resources investigations: U.S. Geological Survey Techniques of WaterResources Investigations, book 2, chap. E1, $126 \mathrm{p}$.

Kolb, C.R., and Van Lopik, J.R., 1958, Geology of the Mississippi River deltaic plain, southeastern Louisiana: Vicksburg, Miss., U.S. Army Corps of Engineers, Technical Report no. 3-483, 120 p.

Kuniansky, E.L., 1989, Geohydrology and simulation of ground-water flow in the "400-foot," "600-foot," and adjacent aquifers, Baton Rouge area, Louisiana: Louisiana Department of Transportation and Development Water Resources Technical Report no. 49,90 p.

Kuniansky, E.L., Dial, D.C., and Trudeau, D.A., 1989, Maps of the "400-foot," "600-foot," and adjacent aquifers and confining beds, Baton Rouge area, Louisiana: Louisiana Department of Transportation and Development Water Resources Technical Report no. $48,16 \mathrm{p}$.

Lovelace, J.K., and Lovelace, W.M., 1995, Hydrogeologic unit nomenclature and computer codes for aquifers and confining units in Louisiana: Louisiana Department of Transportation and Development Water Resources Special Report no. 9, 12 p.

McCulloh, R.P., 1991, Surface faults in East Baton Rouge Parish: Baton Rouge, La., Louisiana Geological Survey Open-File series 91-02, 25 p.

Meyer, R.R., and Rollo, J.R., 1965, Saltwater encroachment, Baton Rouge area, Louisiana: Department of Conservation, Louisiana Geological Survey, and Louisiana Department of Public Works Water Resources Pamphlet no. 17, 9 p. 
Meyer, R.R., and Turcan, A.N., Jr., 1955, Geology and ground-water resources of the Baton Rouge area, Louisiana: U.S. Geological Survey Water-Supply Paper 1296, $138 \mathrm{p}$.

Morgan, C.O., 1961, Ground-water conditions in the Baton Rouge area, 1954-59, with special reference to increased pumpage: Department of Conservation, Louisiana Geological Survey, and Louisiana Department of Public Works Water Resources Bulletin no. 2, 78 p.

Morgan, C.O., 1963, Ground-water resources of East Feliciana and West Feliciana Parishes, Louisiana: Louisiana Department of Public Works, $58 \mathrm{p}$.

Murray, G.E., 1961, Geology of the Atlantic and Gulf Coastal Province of North America: New York, Harper Brothers, $692 \mathrm{p}$.

National Oceanic and Atmospheric Administration, 1995, Climatological data annual summaryLouisiana: Asheville, N.C., Environmental Data Ser vice, $23 \mathrm{p}$.

Nyman, D.J., and Fayard, L.D., 1978, Ground-water resources of Tangipahoa and St. Tammany Parishes, southeastern Louisiana: Louisiana Department of Transportation and Development, Office of Public Works Water Resources Technical Report no. 15, $76 \mathrm{p}$.

Roland, H.L., Hill, T.F., Autin, Peggy, Durham, C.O., and Smith, C.G., 1981, The Baton Rouge and Denham Springs-Scotlandville faults (mapping and damage assessment): Report prepared for the Louisiana Department of Natural Resources, contract no. 2157680-01: Baton Rouge, La., Geological Survey and Durham Geological Associates Consultants, 26 p.

Rollo, J.R., 1960, Ground water in Louisiana: Department of Conservation, Louisiana Geological Survey, and Louisiana Department of Public Works Water Resources Bulletin no. 1, 84 p.

Rollo, J.R., 1969, Saltwater encroachment in aquifers of the Baton Rouge area, Louisiana: Department of Conservation, Louisiana Geological Survey, and Louisiana Department of Public Works Water Resources Bulletin no. 13, 45 p.

Sargent, B.P., 2002, Water use in Louisiana, 2000: Louisiana Department of Transportation and Development Water Resources Special Report no. 15, $133 \mathrm{p}$.

Saucier, R.T., 1994, Geomorphology and Quaternary geologic history of the lower Mississippi Valley: Vicksburg, Miss., U.S. Army Corps of Engineers, 2 v., 364 p., 28 pl.
Smith, C.G., Jr., 1969, Geohydrology of the shallow aquifers of Baton Rouge, Louisiana: Baton Rouge, La., Louisiana State University, Louisiana Water Resources Research Institute Bulletin GT-4, 31 p.

Smoot, C.W., 1988, Louisiana hydrologic atlas map no. 3: Altitude of the base of freshwater in Louisiana: U.S. Geological Survey Water-Resources Investigations Report 86-4314, 1 sheet.

Stuart, C.G., Knochenmus, Darwin, and McGee, B.D., 1994, Guide to Louisiana's ground-water resources: U.S. Geological Survey Water-Resources Investigations Report 94-4085, 55 p.

Tomaszewski, D.J., 1988, Ground-water hydrology of Livingston, St. Helena, and parts of Ascension and Tangipahoa Parishes, southeastern Louisiana: Louisiana Department of Transportation and Development Water Resources Technical Report no. 43, 54 p.

Tomaszewski, D.J., 1996, Distribution and movement of saltwater in aquifers in the Baton Rouge area, Louisiana, 1990-92: Louisiana Department of Transportation and Development Water Resources Technical Report no. 59, 44 p.

Turcan, A.N., Jr., 1966, Calculation of water quality from electrical logs--theory and practice: Department of Conservation, Louisiana Geological Survey, and Louisiana Department of Public Works Water Resources Pamphlet no. 19, 23 p.

Viewlog Systems, 2004, Viewlog borehole data management system (manual): Viewlog Systems, Toronto, Ontario, Canada, $465 \mathrm{p}$.

Whiteman, C.D., Jr., 1972, Ground water in the Plaquemine-White Castle area, Iberville Parish, Louisiana: Department of Conservation, Louisiana Geological Survey, and Louisiana Department of Public Works Water Resources Bulletin no. 16, 69 p.

Whiteman, C.D., Jr., 1979, Saltwater encroachment in the "600-foot" and "1, 500-foot" sands of the Baton Rouge area, Louisiana, 1966-78, including a discussion of saltwater in other sands: Louisiana Department of Transportation and Development, Office of Public Works Water Resources Technical Report no. 19, $49 \mathrm{p}$.

Winner, M.D., Jr., 1963, The Florida Parishes--an area of large, undeveloped ground-water potential in southeastern Louisiana: Louisiana Department of Public Works, $50 \mathrm{p}$.

Winner, M.D., Jr., Forbes, M.J., Jr., and Broussard, W.L., 1968, Water resources of Pointe Coupee Parish, Louisiana: Department of Conservation, Louisiana Geological Survey, and Louisiana Department of Public Works Water Resources Bulletin no. 11, 110 p. 


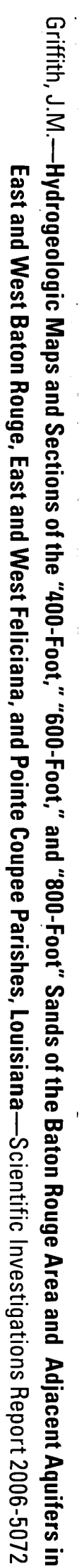

(9) Printed on recycled paper 
In cooperation with

Capital Area Ground Water Conservation Commission

Hydrogeologic Maps and Sections of the "400-Foot," "600Foot," and "800-Foot" Sands of the Baton Rouge Area and Adjacent Aquifers in East and West Baton Rouge, East and West Feliciana, and Pointe Coupee Parishes, Louisiana

Scientific

Investigations Report

2006-5072

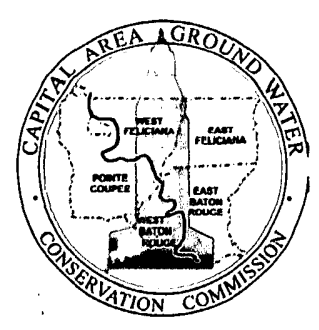

U.S. Department of the Interior

U.S. Geological Survey 